\title{
Chapter 14 \\ Economics of Land Degradation and Improvement in Ethiopia
}

\author{
Samuel Gebreselassie, Oliver K. Kirui and Alisher Mirzabaev
}

\begin{abstract}
Land degradation is an important problem in Ethiopia, with more than $85 \%$ of the land degraded to various degrees. Recent estimates using satellite imagery show that land degradation hotspots over the last three decades cover about $23 \%$ of the land area in the country. The assessment of nationally representative household survey shows that important drivers of sustainable land management in Ethiopia are biophysical, regional and socio-economic determinants. Specifically, access to agricultural extension services and markets and secure land tenure are important incentives to adoption of sustainable land management practices. Thus, policies and strategies relating to securing tenure rights, building the capacity of land users through access to extension services, and improving access to input, output and financial markets should be considered in order to incentivize sustainable land management. Important local level initiatives and institutions to manage grazing lands and forests through collective action should also be encouraged. We use the Total Economic Value approach (TEV) to estimate the cost of land degradation in Ethiopia. The annual cost of land degradation associated with land use and cover change in Ethiopia is estimated to be about $\$ 4.3$ billion. Only about $51 \%$ of this cost of land degradation represents the provisioning ecosystem services. The remaining $49 \%$ represent the loss of supporting and regulatory and cultural ecosystem services. Use of land degrading practices in maize and wheat farms resulted in losses amounting to $\$ 162$ million-representing $2 \%$ equivalent of the GDP in 2007. The costs of action to rehabilitate lands degraded during the 2001-2009 period through land use and cover change were found to equal about $\$ 54$ billion over a 30-year horizon, whereas if nothing is done, the resulting losses may equal almost $\$ 228$ billion during the same period. Thus, the costs of action against land degradation are lower than the costs of inaction by about 4.4 times over
\end{abstract}

O.K. Kirui $(\bowtie) \cdot$ A. Mirzabaev

Center for Development Research (ZEF), University of Bonn, Walter-Flex Str. 3,

53115 Bonn, Germany

e-mail: okirui@uni-bonn.de; oliverkk@yahoo.com

S. Gebreselassie

Ethiopian Economic Policy Research Institute (EEPRI), Ethiopian Economic Association,

Yeka, Addis Ababa, Ethiopia

(C) The Author(s) 2016

E. Nkonya et al. (eds.), Economics of Land Degradation

and Improvement - A Global Assessment for Sustainable Development,

DOI 10.1007/978-3-319-19168-3_14 
the 30 year horizon; implying that a dollar spent to rehabilitate degraded lands returns about 4.4 dollars in Ethiopia.

Keywords Economics of land degradation - Drivers of land degradation • Sustainable land management $\cdot$ Cost of land degradation

\section{Introduction}

Ethiopia is one of the most highly populated countries in Africa with about 92 million people (United Nations, 2012, cited by World Bank 2013). Rain-fed agriculture employs $80 \%$ of the population, forming the basis of Ethiopia's economy. Despite a consistent, relatively high growth over the past decade (CSA 2013), the agricultural sector is still characterized by subsistence nature and low productivity. The reasons for this low productivity are many and complex. Environmental degradation, as exhibited in land and water resources' degradation together biodiversity loss, remains a key development challenge for the Ethiopian agriculture.

Ethiopia experiences several types of land degradation ranging from water and wind erosion; salinization (and recently acidification); and physical and biological soil degradation. The Global Mechanism (2007) estimated that over $85 \%$ of the land in Ethiopia is moderately to very severely degraded, and about $75 \%$ is affected by desertification. Soil erosion, with its associated loss of fertility and rooting depth, water resource degradation and loss of bio-diversity (Eyasu 2003), is a key problem that undermines land productivity in the highlands of Ethiopia. Soil erosion is particularly serious in the high and low potential cereal zones of the north-central highlands. In regions such as Wolo, Tigray and Harerge, $50 \%$ of the agricultural lands have soils with depths less than $10 \mathrm{~cm}$, which make them unsuitable for farming (Eyasu 2003; Kidane 2008).

The costs of land degradation, which has been going on for centuries in Ethiopia (Kidane 2008), are substantial and include both direct and indirect costs, such as on-farm soil nutrient loss (direct) and other indirect losses, such as lower food security and higher poverty (Berry 2003).

Farmers in different parts of the country realize soil erosion as an immediate threat to their livelihood and apply different traditional soil and water conservation practices. Despite some positive progress over time, the impact of investments in remedial actions is either hard to quantify (or less researched), but seems to be of scale smaller than the scope and the complexity of the problem. Under the prevailing natural and socio-economic conditions, farmers in most parts of the country cannot cope with the rapid rate of soil erosion and nutrient mining. With a continued population growth, the problem is likely to persist in the future (Shiferaw and Holden 1999).

Most studies conducted on the cost of land degradation in Ethiopia indicate that land degradation is one of the most serious problems facing the country's agriculture and food security. Some authors (von Braun et al. 2013, 2014) even warn that 'eradicating extreme poverty without adequately addressing land degradation is 
highly unlikely'. The proximate drivers of land degradation in Ethiopia include forest clearance and soil surface exposure (high removal of vegetative cover); detrimental cultivation practices with emphasis on small-seed crops that require a fine tillage; and overgrazing. Due to land shortage and lack of alternative livelihoods, farmers cultivate lands that have slopes more than $60 \%$ with shallow and stony soils prone to erosion. Slopes more than $30 \%$ should not normally be used for agricultural purposes, but rather allocated to natural vegetation or forestry. However, in Ethiopia there is no land use policy that prohibits farmers from using such lands and thus, more and more marginal lands are cultivated (Eyasu 2003). Several factors including poverty, land fragmentation and high human and livestock population pressure act more indirectly as driving forces for land degradation. Pressure from human and livestock leads huge removal of vegetation cover to meet increasing crops, grazing and fuel wood demand.

Despite a vast accumulation of knowledge and evidence on the impacts of land degradation and a well-documented database of its proximate and underlying causes, progress to address the problem is at best mixed. The Ethiopian government reaffirms its commitment to address the problem in its official policies, stated in the Growth and Transformation Plan (GTP) yet the undertaking and investments to halt the problem are far lower than the scope and the complexity of the problem. Natural resource management and conservation has been taken up as an important intervention in all parts of Ethiopia. The overwhelming proportion of these activities is accomplished through popular participation (mass mobilization). But it is not clear to what extent these initiatives are based on evidence on the ground. In addition, these interventions are yet to deliver results.

Most of the prescriptions to tackle the problem such as the numerous conservation programs financed through food/cash aid projects, for instance, focus excessively on technical solutions, to the negligence (or inadequate attention) to policy and institutional factors. Genanew and Alemu (2012) indicate that "policies and programs were adopted based on incorrect assumptions and little understanding of the incentives and constraints related to land conservation-which could be misleading". These problems are compounded by little previous research (Shiferaw and Holden 1999). As time passes, the dynamics and complexity of the problem have been increasing due to a host of factors such as population growth, poverty effects, climate effects, etc.

Mitigating land degradation and fostering sustainable land management practices needs a suitable policy framework that sufficiently accounts for the interest of present and future generations in a dynamic and evolving environment. Consequently, actions to prevent and reverse the problem should consistently be based on context specific and continuous research findings. Recognizing the extent of land degradation and its impact on rural food security and livelihoods of rural people, the Ethiopian Government, with aid from several international agencies, initiated a massive program of soil conservation and rehabilitation in the worst affected areas since early 1980s (Eyasu 2003). Since then both the government and donors initiated large-scale soil conservation programs that implement a variety of conservation measures (terraces, bunds, tree planting, and closure of grazing areas 
etc.). There exists little information on the impact of these actions. The efforts to address the problem become more complicated because there is not sufficient emphasis on institutional and participation issues (Berry 2003). It is, therefore, important to study the role of such factors as well as the political economy of implementing technical remedies (or the transaction costs of policy and institutional reforms required to implement identified technical remedies).

Given the extent of the land degradation problem and a limited impact of interventions so far made both by the government and the international community, the country needs to revisit shortcomings (in existing strategies, projects and programs) that hamper sustainable land management and development. Efforts should be made to identify gaps and opportunities in existing (technical) knowledge as well as in policy and institutional factors that hamper or facilitate the implementation of technical remedies.

Many of the land ecosystems services are not transacted in markets, thus different actors do not pay for negative or positive effects on those ecosystems. Thus, farmers do not consider the value of these externalities their land-use decision. This eventually leads to an undervaluation of land and its provision of ecosystem services (Nkonya et al. 2013). On the other hand, institutional issues like communal or public ownership of farm lands as well as high poverty/food insecurity level make efforts to address land degradation difficult and complex.

The present study aims to contribute to the knowledge and on-going discussions on addressing land degradation in Ethiopia by it analysis of key proximate and underlying drivers of land degradation and sustainable land management (SLM) in in the country and by estimating and comparing the costs and benefits of action versus costs of inaction against land degradation in Ethiopia.

\section{Literature Review}

\section{Land Degradation in Ethiopia}

The most common form of land degradation in Ethiopia is soil erosion by water. Soil erosion is indeed considered the most significant environmental challenge to the food security of the population and future development prospects of the country (Wagayehu 2003). A considerable volume of information has been produced since the mid-1980s regarding soil erosion in Ethiopia (Barbier 1989, 2000; FAO 1986; Hurni 1993 among others, all cited Eyasu 2003). But there is a lack of reliable and consistent data on the extent and rate of soil loss (tones/ha/year). Different data sources report different estimates on the amount of soil loss from arable land. As shown below in Table 14.1, the current rates of soil erosion in Ethiopia are estimated to vary between 42 and 300 tones/ha/year.

The wide range of estimates in soil erosion rate is indicative of the complex patterns of spatial and temporal variations and conceptual and methodological difficulties inherent in making such estimates. Obviously there is considerable 
Table 14.1 Estimates of rates of soil loss on croplands in Ethiopia

\begin{tabular}{l|l|l}
\hline Author & $\begin{array}{l}\text { Estimates of annual soil loss } \\
\text { from arable land (t/ha/year) }\end{array}$ & Method used \\
\hline FAO/EHRS 1986 & 130 & $\begin{array}{l}\text { USLE: universal soil loss equation } \\
\text { and guess estimates }\end{array}$ \\
\hline $\begin{array}{l}\text { Hurni 1988: soil } \\
\text { conservation research } \\
\text { project }\end{array}$ & 42 & $\begin{array}{l}\text { Measurement from runoff plots } \\
\text { from eight stations across the } \\
\text { country }\end{array}$ \\
\hline Belay Tegene 1992 & 75 & Measurement from runoff plots \\
\hline Azene Bekele 1997 & 100 & Guess estimate \\
\hline Tamire Hawndo 1996 & 300 & Secondary data and estimates \\
\hline
\end{tabular}

Source Eyasu (2003)

variability of erosion rates over time and place depending on agro-ecological zone and soil type. Soil erosion occurs at varying rates and with varying degrees in different parts of the country. Deforestation, forest burning and expansion of cultivated lands to marginal lands have also contributed to the widespread problem of land degradation in the country. 'About $70 \%$ of Ethiopia's highland population and an area of over 40 million ha are affected by land degradation' (Melaku 2013), indicating the scale and extent of the problem confronting the country.

\section{Economic Studies of Land Degradation in Ethiopia}

Land degradation has high economic costs in Ethiopia. There exist several studies dealing with land degradation at the national level in Ethiopia. Some of these studies include; the Highlands Reclamation Study by FAO in 1986; the Ethiopian Forestry Action Plan (1993), the National Conservation Strategy Secretariat (Sutcliffe 1993), the Effect of Soil Degradation on Agricultural Productivity in Ethiopia by Keyser and Sonneveld in 2001 (see Berry 2003; Eyasu 2003) and the Economics of Soil and Water Conservation by Wagayehu (2003). These studies investigate a wide range of issues ranging from the causes, nature, extent and economic cost of the land degradation problem to the potential remedial actions necessary to tackle the problem.

Though the conclusions from these studies vary in detail, many of the authors argued on the following few silent points. First, many argue that Ethiopia has a long history of widespread and serious land degradation in all of its regions. Second, the 'problem of land degradation attracted the attention of policy-makers only after the consequences became felt during recent decades' (Wagayehu 2003; Shiferaw and Holden 1999; Shibru and Kifle 1998 cited by Kidane 2008) when the Ethiopian Government, with aid from the international agencies, initiated a massive program of soil conservation and rehabilitation in the worst affected areas. Third, most of the remedial measures focused largely on physical structures including terracing, bunds, tree planting and, to some extent, closure of grazing areas, as well as increased use of 
chemical fertilizers and relatively high negligence of policy and institutional issues (Berry 2003; Eyasu 2003; The Global Mechanism 2007), which has greatly reduced the impact as well as sustainability of investments on SLM. Despite all the extension efforts, there is a steadily increasing rate of land degradation.

Based on findings of previous studies, the next section tries to identify and examine the drivers of land degradation in Ethiopia and its impacts on rural livelihoods and food security. It also reviews the stock of knowledge on sustainably managing agricultural land and preventing and mitigating the impacts of land degradation. It also tries to identify gaps in knowledge for future studies.

\section{Drivers of Land Degradation in Ethiopia}

Poor land-use practices and population pressure are the major drivers of land degradation in Ethiopia (Genanew and Alemu 2012; Berry 2003). High population pressure, especially in the highland, has led to a decline in arable area, which in turn led to agricultural encroachment onto marginal areas. Several other factors contribute to the unsustainable land management in Ethiopia. The patterns of land ownership and government control, low levels of investment in agriculture and animal husbandry, poor rural infrastructure and markets and low levels of technology are cited as the underlying causes of land degradation by Berry (2003). Policy failures and lack of capacity to implement government interventions also contribute to land and other resource degradation (The Global Mechanism 2007; Wagayehu 2003).

The less-than-desired and largely unsustainable impact of series of conservation measures usually involving physical structures such as terraces, bunds and tree planting, among others, is explained by lack of policy action or framework that is essential to address (or minimize the effect of) the externalities of benefits or costs associated with participation or lack of participation in such programs (by farmers). This problem is attributed to the relative negligence of policy and institutional factors in the numerous conservation programs financed through food/cash aid projects (Berry 2003; Eyasu 2003). This problem is compounded by little evidence-based and action-oriented research (Shiferaw and Holden 1999; von Braun et al. 2013).

Another key driver of the problem is a lack of capacity and/or commitment to address the problem appropriately. Inconsistent, partial or insufficient interventions reinforce the problem while eroding the capacity of farmers/the real victims/and local authorities to deal with the problem fundamentally. Most interventions focus on addressing the symptoms of the problem (i.e. reducing the human cost of the problem, distress sales of assets) at the expense of long-term and long-lasting solutions. In other words, by focusing on short-term solutions, such interventions encourage inaction or the postponement of real-actions (i.e. actions by beneficiaries and authorities to address the root cause of the problem).

A review to document various proximate and underlying drivers of land degradation in Eastern Africa, including Ethiopia, has been carried out by Kirui and 
Table 14.2 Proximate and underlying drivers of land degradation in Ethiopia

\begin{tabular}{|c|c|c|}
\hline Proximate drivers & Underlying drivers & References \\
\hline $\begin{array}{l}\text { Topography, unsustainable } \\
\text { agriculture, fuel wood } \\
\text { consumption, conversion } \\
\text { of forests, woodlands, } \\
\text { shrub-lands to new } \\
\text { agricultural land } \\
\text { (deforestation) }\end{array}$ & $\begin{array}{l}\text { Weak regulatory } \\
\text { environment and institutions, } \\
\text { demographic growth, unclear } \\
\text { user rights, low } \\
\text { empowerment of local } \\
\text { communities, poverty, } \\
\text { infrastructural development, } \\
\text { population density }\end{array}$ & $\begin{array}{l}\text { Pender et al. (2001), Jagger } \\
\text { and Pender (2003), Holden } \\
\text { et al. (2004), Rudel et al. } \\
\text { (2009), Bai et al. (2008), } \\
\text { Belay et al. (2014), Tesfa and } \\
\text { Mekuriae (2014) }\end{array}$ \\
\hline
\end{tabular}

Source Kirui and Mirzabaev (2014)

Mirzabaev (2014). A summary for Ethiopia is presented in Table 14.2. Important proximate drivers of land degradation include; topography, unsustainable agricultural practices, and land cover change (forests, woodlands, and shrub-land conversion to new agricultural land uses). Similarly, the pertinent underlying drivers of land degradation include weak policy and regulatory environment and institutions, poverty, demographic growth, low empowerment of local communities, infrastructural development and unclear user rights (especially land tenure).

\section{Impacts of Land Degradation on Rural Livelihoods and Food Security}

Land degradation has a negative implication to household food security status and contributes directly to the reduction in livelihoods among the rural communities in Ethiopia. The immediate consequence of land degradation is lower crop yields, leading to higher poverty rates among agricultural households. Based on a review of recent studies conducted by a range of institutions and scientists, the Global Mechanism to Combat of Desertification of the UN (UNCCD) shows that the country loses about 30,000 ha of agricultural land annually due to water erosion, and more than 2 million ha are degraded (National Review Report 2002). Based on experts' opinion, Dregne (1991) recounted an irreversible soil productivity loss in about $20 \%$ of Ethiopia agricultural land due to water erosion. Ethiopia loses an estimated 1 billion tons of topsoil annually as a result of soil erosion alone (Berry 2003). Further losses of about $\$ 23$ million of forest as a result of deforestation and $\$ 10$ million of livestock capacity are also reported annually (Yesuf et al. 2005).

In addition to these estimates on the rate and extent of land degradation via soil erosion, deforestation, over-grazing etc., many other studies provide quantitative estimates on the cost of land degradation. A study by Teketay (2001), for instance, estimates that "reduced soil depth caused by erosion resulted in a grain production loss of 57,000 (at $3.5 \mathrm{~mm}$ soil loss) to 128,000 tons (at $8 \mathrm{~mm}$ soil depth) in 1990 alone. It has been estimated that the grain production lost due to land degradation in 1990 would have been sufficient to feed more than four million people" (Teketay 2001). Similarly, Berry (2003) estimates that land degradation and other 
unsustainable land management practices cost the country (via loss of soil and essential nutrients) about three percent of its agricultural Gross Domestic Product (GDP) or \$106 million (1994\$). Bojö and Cassells (1995) also estimate that Ethiopia loses about $3 \%$ of the agricultural gross domestic production due to soil erosion and nutrient loss. While modelling the impact of water erosion on food production in Ethiopia, Sonneveld (2002) reported a range of potential reduction in production of $10-30 \%$ by 2030 .

The most critical and urgent on-site impact of soil erosion to the farmers are decline in both the current and potential crop and livestock yields - which translate into income loses. The consequences of soil erosion may also be viewed in the need to use more inputs to maintain soil productivity so as to attain the same level of yield (Wagayehu 2003). The impact of land degradation on agricultural productivity represents an on-site cost. However, soil erosion from agricultural fields has also serious external or off-site effects, which indirectly affect the rest of society. The external effects of soil erosion are caused by sedimentation of hydroelectric dams, pollution of municipal water reservoirs, ponds, etc. For instance, the hydroelectric generation capacity of the Koka dam, one of the major dams in Ethiopia, is severely affected by sedimentation. It is estimated that about $30 \%$ of the total storage volume of the reservoir has already been lost to sedimentation (EEPC 2002, cited by Eyasu 2003), which had a negative impact on the annual energy generation from the plant. The effect of land use change (such as expansion of the agricultural frontier and the migration of households and communities towards pastoral land, fragile ecosystem) is another off-site (or on-site) effect of soil erosion (Kirui and Mirzabaev 2014).

Other off-site environmental effect of land degradation due to soil erosion and deforestation include its effect on the biodiversity of the country and many ecosystem services (e.g. nutrient cycling, soil formation), regulating (e.g. flood regulation, water purification), cultural, spiritual and recreational services for the present and future generations (Nkonya et al. 2011).

\section{Methods and Data}

The empirical approaches used to estimate the determinants of SLM adoption and the number of SLM technologies adopted are discussed in detail in this section. These methods are based on the methodological Chap. 2, and are consistently applied throughout several case studies in this volume, specifically, in Chaps. 16 and 20 .

\section{Determinants of SLM Adoption: Logit Regression Model}

Land degradation usually occurs due to lack of sustainable land management practices. Factors preventing households from adopting SLM practices are also 
likely to cause land degradation. Therefore, analyzing the drivers of SLM is similar in its implications as analyzing the drivers of land degradation. The adoption of SLM technologies/practices in this study refers to use of one or more SLM technologies in a given plot.

The adoption of SLM technology/practice in a farm plot was measured as a binary dummy variable $(1=$ adopted SLM in a farm plot, $0=$ otherwise). The two appropriate approaches to estimate such binary dummy dependent variable regression models are the logit and the probit regression models. Here we use the logit model.

The reduced form of the logit model applied to nationally representative agricultural household survey data from Ethiopia is presented as:

$$
\mathrm{A}=\boldsymbol{\beta}_{0}+\boldsymbol{\beta}_{1} x_{1}+\boldsymbol{\beta}_{2} \boldsymbol{x}_{2}+\boldsymbol{\beta}_{3} \boldsymbol{x}_{3}+\boldsymbol{\beta}_{4} \boldsymbol{x}_{4}+\boldsymbol{\beta}_{5} z_{i}+\boldsymbol{\varepsilon}_{i}
$$

where, $\mathrm{A}=$ Adoption of SLM technologies; $\mathrm{x}_{1}=\mathrm{a}$ vector of biophysical factors (climate conditions, agro-ecological zones); $\mathrm{x}_{2}=\mathrm{a}$ vector of demographic characteristics factors (level of education, age, gender of the household head); $\mathrm{x}_{3}=\mathrm{a}$ vector of farm-level variables (access to extension, market access, distance to market, distance to market); $\mathrm{x}_{4}=$ vector of socio-economic and institutional characteristics (access to extension, market access, land tenure, land tenure); $z_{i}=$ vector of country fixed effects; and is the error term.

Robust checks are carried out to check these misspecifications. Further, assessment beyond adoption to intensity (number) of SLM adoption can also counter such inherent weakness. We explore this option in our study.

\section{Determinants of Number of SLM Technologies Adopted: Poisson Model}

The number of SLM technologies and the corresponding proportion of plots in which these technologies were applied are as presented in Table 14.8. The number of SLM technologies is thus a count variable (ranging from 0 to 6 in our case). Thus the assessment of the determinants of the number of SLM technologies adopted requires models that accounts for count variables. For this reason, here we apply the Poisson regression model (PRM). The reduced form of the Poisson regression is presented as follows:

$$
\mathrm{A}=\boldsymbol{\beta}_{0}+\boldsymbol{\beta}_{1} \boldsymbol{x}_{1}+\boldsymbol{\beta}_{2} \boldsymbol{x}_{2}+\boldsymbol{\beta}_{3} \boldsymbol{x}_{3}+\boldsymbol{\beta}_{4} \boldsymbol{x}_{4}+\boldsymbol{\beta}_{5} z_{i}+\boldsymbol{\varepsilon}_{i}
$$

where, $\mathrm{A}=$ Number of SLM technologies adopted; and the vector of explanatory variables $\mathrm{x}_{\mathrm{i}}$ are similar to those used in Eq. 14.1; (i.e. $\mathrm{x}_{1}=\mathrm{a}$ vector of biophysical factors (climate conditions, agro-ecological zones) $\mathrm{x}_{2}=\mathrm{a}$ vector of demographic characteristics factors (level of education, age, gender of the household head); $\mathrm{x}_{3}=$ a vector of farm-level variables (access to extension, market access, distance to market, distance to market); $\mathrm{x}_{4}=$ vector of socio-economic and institutional 
characteristics (access to extension, market access, land tenure, land tenure); $\mathrm{z}_{\mathrm{i}}=$ vector of country fixed effects; and is the error term).

\section{Cost of Action Verses Inaction Against Degradation}

Refer to Chap. 6 of this volume for a comprehensive discussion on the empirical strategy to estimate the costs of land degradation (due to LUCC and due to use of land degrading practices) and also the empirical strategy to estimate the costs of taking action against land degradation.

\section{Data and Sampling Procedure}

This study uses the Ethiopia Rural Socioeconomic Survey (ERSS) data collected during the period October 2011-March 2012 by the Central Statistical Agency (CSA) in Ethiopia. The ERSS sample is designed to be representative of rural and small town areas of Ethiopia. Based on population estimates from the 2007 Population Census, the CSA categorizes a town with a population of less than 10,000 inhabitants as small. The ERSS rural sample is a sub-sample of the Annual Agricultural Sample Survey (AgSS) while the small town sample comes from the collection of small town Enumeration Areas (EAs).

The sample is a two-stage probability sample. The first stage of sampling entailed selecting primary sampling units - the CSA's enumeration areas (EAs). For the rural sample, 290 enumeration areas were selected from the AgSS enumeration areas based on probability proportional to size of the total enumeration areas in each region. For small town EAs, a total of 43 EAs were selected. The second stage involved a random selection of households to be interviewed in each EAs. For rural EAs, a total of 12 households were sampled in each EA. Of these, 10 households were randomly selected from the sample of $30 \mathrm{AgSS}$ households.

The AgSS households are households which are involved in farming or livestock activities. Another 2 households were randomly selected from all other households in the rural EA (those not involved in agriculture or livestock production). In some EAs, there is only one or no such households, in which case, less than two non-agricultural households were surveyed and more agricultural households were interviewed instead so that the total number of households per EA remains the same. In the small town EAs, 12 households are selected randomly from the listing of each EA, with no stratification as to whether the household is engaged in agriculture/livestock. Households were not selected using replacement. The sample covers a total of 3969 households (24,954 farm plots). 


\section{Choice of Independent Variables for Econometric Estimations}

The choice of relevant independent variables is based on economic theory, empirical review of previous literature, and data availability. These variables have been grouped as biophysical, demographic, plot, and socio-economic variables. Brief descriptions alongside the direction of the hypothesized effects of these variables on SLM adoption are presented in Table 14.3. The positive sign means a positive relationship is expected, while the minus sign means that a negative relationship is expected. When both plus and minus signs are given, there are no specific theory-based expectations made, but the relationship is considered a matter of empirical investigation.

Table 14.3 Definitions of hypothesized explanatory variables

\begin{tabular}{l|l|l}
\hline Variable & Definition & $\begin{array}{l}\text { Hypothesized effect on SLM } \\
\text { adoption }\end{array}$ \\
\hline Temperature & Annual mean temperature $\left({ }^{\circ} \mathrm{C}\right)$ & $+/-$ \\
\hline Rainfall & Annual mean rainfall $(\mathrm{mm})$ & $+/-$ \\
\hline Land cover & Land cover type & $+/-$ \\
\hline Soils & Soil rooting conditions, soil type & $+/-$ \\
\hline AEZ & Agro-ecological zone & $+/-$ \\
\hline Slope & Slope elevation (SRTM) & $+/-$ \\
\hline Age & Age of household head (years) & $+/-$ \\
\hline Gender & Gender of household head & + \\
\hline Education & $\begin{array}{l}\text { Years of formal education of HH } \\
\text { head }\end{array}$ & + \\
\hline Family size & $\begin{array}{l}\text { Size of household (adult } \\
\text { equivalent })\end{array}$ & $+/-$ \\
\hline Tenure & Land tenure status of the plot & + \\
\hline Soil type & Soil type of the plot & $+/-$ \\
\hline Extension & Access to agricultural extension & $+/-$ \\
\hline Market dist. & Distance from plot from the market & - \\
\hline Assets value & Value of household assets & + \\
\hline Plot size & Size of the plot & + \\
\hline Credit access & Amount of credit accessed & + \\
\hline $\begin{array}{l}\text { Group } \\
\text { membership }\end{array}$ & $\begin{array}{l}\text { Membership in } \\
\text { cooperatives/SACCOs }\end{array}$ & + \\
\hline Irrigation & Access to irrigation water & + \\
\hline Source Auth & &
\end{tabular}

Source Authors' compilation 


\section{Results and Discussion}

\section{Extent and Trends of Land Degradation in Ethiopia}

The use of satellite-based imagery and remote sensing techniques to identify the magnitude and processes of land degradation at different levels has increased recently. This involves the use of Normalized Difference Vegetation Index (NDVI) derived from Advanced Very High-Resolution Radiometer (AVHRR) data. This approach was previously used by Evans and Geerken (2004), Bai et al. (2008), Hellden and Tottrup (2008), and Vlek et al. (2010). Using this technique, Bai et al. (2008) estimated that about $26 \%$ of Ethiopian territory was experiencing land degradation processes between the periods 1981-2003; affecting about $30 \%$ of the population over the same period (Table 14.4).

More recently, Le et al. (2014), Chap. 4, carried out an assessment using improved techniques which correct for the effect of atmospheric and chemical fertilizations, and rainfall factors. Unlike the study by Bai et al. (2008), their estimation also considers the major land use/cover types of every country covered in their study. The results for Ethiopia (Fig. 14.1) show that land degradation occurred in about 228,160 $\mathrm{km}^{2}$ (or $23 \%$ of total land area) between 1982 and 2006. A look at land use land cover types shows that the areas that experienced much degradation include sparse vegetation (32\%), mosaic forest-shrub/grass (27\%), shrub-land $(20 \%)$ and mosaic vegetation-crop (19\%). These degradation and improvement hotspots are depicted in Fig. 14.1.

Land degradation can occur in two ways - either through productivity decline as a result of such factors as soil erosion, nutrient depletion and mining or changes in land use/land cover (from more economically and environmentally productive land

Table 14.4 Statistics of degrading areas for Ethiopia (1981-2003)

\begin{tabular}{l|l|l|l|l|l}
\hline \multicolumn{2}{l|}{ Degraded area } & Population affected & Total NPP loss \\
\hline $\mathrm{Km}^{2}$ & $\begin{array}{l}\% \text { territory } \\
\text { (of the country) }\end{array}$ & $\begin{array}{l}\% \text { of global } \\
\text { degraded area }\end{array}$ & Number & $\begin{array}{l}\% \text { of total } \\
\text { population }\end{array}$ & (ton C/23 years) \\
\hline 296,812 & $26.3 \%$ & $0.84 \%$ & $20,650,316$ & $29.1 \%$ & $14,276,065$ \\
\hline
\end{tabular}

Source Adapted from Bai et al. (2008)

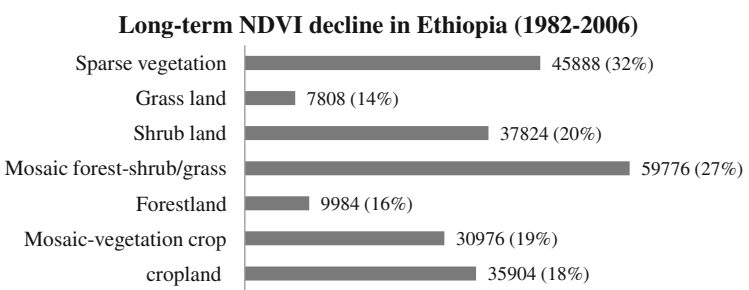

Fig. 14.1 Long-term NDVI decline in Ethiopia (1982-2006)-Area in $\mathrm{km}^{2}$ and \%. Source Calculated from Le et al. (2014) 
uses/covers to a less economically and environmentally one). Based on high quality satellite data from Moderate Resolution Imaging Spectroradiometer (MODIS), the next section discuss changes in land use and cover for Ethiopia during the 2001 and 2009 period.

\section{Land Degradation as a Result of Land Use Change}

Results from our assessment presents a dynamic land use and land cover changes in Ethiopia over the 2001-2009 periods. Table 14.5 presents the different shares of land use land cover types for the period 2001 and 2009. For example, in 2001 there were about 8.5 million ha of cropland, 5.5 million ha of forest land and about 29 million ha of grassland. In 2009 however, cropland increased to 11.3 million while forests and grasslands decreased to 4.1 and 25.5 million ha respectively. The detailed land use and land cover (LULC) change by region is presented in Table 14.5.

Table 14.6 presents percentage change in LULC change by region and nationally; with year 2001 as a baseline. Nationally, results show significant increases in the cropped area (33\%) and shrublands (7\%). Significant losses were reported in forests $(26 \%)$, grasslands $(11 \%)$, and water $(8 \%)$. About $12 \%$ of barren land was also brought into use during this period. There was no significant change in the urban land. There are variations however by region as described below.

While substantial increases are reported for cropped land in Harari (750 \%), Gambela (101\%), Addis Ababa (55\%), Amhara (54\%) and Tigray (48 \%); significant decreases were reported in Benshangul (65\%), Afar (36\%) and Somali (29\%) regions. These changes may be associated to the conversion of forests and grasslands to cropland.

Table 14.5 Changes in land use land cover classification in Ethiopia between 2001 and 2009 (million ha)

\begin{tabular}{|c|c|c|c|}
\hline $\begin{array}{l}\text { Land } \\
\text { use/cover }\end{array}$ & 2001 & 2009 & $\begin{array}{l}\text { Percentage change } \\
(\%)\end{array}$ \\
\hline Cropland & 8.51 & 11.30 & 32.7 \\
\hline Forest & 5.49 & 4.07 & -25.9 \\
\hline Grassland & 28.50 & 25.50 & -10.5 \\
\hline Shrublands & 41.80 & 44.60 & 6.7 \\
\hline Woodland & 22.40 & 22.00 & -1.8 \\
\hline Urban & 0.07 & 0.07 & 0.1 \\
\hline Barren & 5.65 & 4.96 & -12.2 \\
\hline Water & 0.64 & 0.59 & -7.8 \\
\hline Total & 113.06 & 113.08 & - \\
\hline
\end{tabular}

Source Calculated based on Nkonya et al. (2014), using MODIS data 
Table 14.6 Change in land use land cover in Ethiopia in 2009 relative to 2001 (\%)

\begin{tabular}{l|c|l|l|c|l|l|r|r}
\hline Region & Cropland & Forest & Grassland & Shrublands & Woodland & Urban & Barren & Water \\
\hline Addis Ababa & 54.8 & -82.6 & -13.5 & 134.6 & -60.1 & 0.0 & 0.0 & 0.0 \\
\hline Afar & -36.3 & 3.5 & -23.5 & 44.8 & -77.8 & 0.0 & -22.5 & -28.9 \\
\hline Amhara & 53.9 & -72.9 & 6.5 & -6.6 & -47.2 & 1.1 & -7.7 & -2.1 \\
\hline Benshangul & -64.7 & -89.5 & -1.3 & 658.3 & 3.6 & 0.0 & 0.0 & 0.0 \\
\hline Dire Dawa & 7.8 & -100 & -69.7 & 114.3 & -1.7 & 0.0 & 0.0 & 0.0 \\
\hline Gambela & 101.1 & 31.6 & -60.4 & 1622.2 & 34.3 & 0.0 & -53.3 & 26.5 \\
\hline Harari & 750.0 & -89.8 & -43.2 & 49.8 & -57.1 & 0.0 & 0.0 & 0.0 \\
\hline Oromia & 21.4 & -30.5 & -11.2 & 2.2 & 13.5 & 0.0 & -1.6 & -8.1 \\
\hline Somali & -29.4 & -90.3 & -45.7 & 70.0 & -15.9 & 0.0 & 0.0 & 0.0 \\
\hline Southern & 31.9 & -15.9 & -8.5 & 0.4 & 5.8 & 0.0 & -59.5 & -11.7 \\
\hline Tigray & 48.0 & -95.8 & -24.7 & 61.6 & -55.6 & 0.0 & -25.3 & -36.6 \\
\hline Total & 32.9 & -25.8 & -10.5 & 6.7 & -1.8 & 0.1 & -12.3 & -7.8 \\
\hline Source Cal & & & & & & & &
\end{tabular}

Source Calculated based on Nkonya et al. (2014), using MODIS data

A closer look in the table shows that forests decreased in all the regions (shift to cropland and shrublands) ranging from (16-100 \%) except in Afar and Gambela where it increased by $4 \%$ and $32 \%$ respectively. Similarly, grasslands decreased in all regions by about 9-70 \% except only in Amhara region where it increased by about $7 \%$. The other important LULC change is the decrease of woodlands (shift to cropland and shrublands) in all regions except some reported increase in Southern (6\%), Oromia (14\%) and Gambela (34\%) regions.

\section{Economic Costs of Land Degradation}

As discussed earlier, several studies have previously tried to impute the costs and consequences of land degradation in Ethiopia. However, most of these studies estimated the cost of degradation via proxies such as productivity losses, cost of siltation to dams, the additional costs of increased input usage (especially fertilizer etc.). In this study, we estimate the costs of land degradation associated with LULC change following the TEV framework. Total Economic Value (TEV) refers to the total value of ecosystem services. TEV of the ecosystem is reported as the sum of use values and non-use values of the ecosystem services, both market and non-market ecosystem services. Further description of the TEV framework is presented by Nkonya et al. (2011), Kumar (2010) and Chap. 6 of this book.

A summary of the TEV for Ethiopia as well as its relationship to GDP are presented in Table 14.7. Our results show that there was a decline in the TEV between 2001 and 2009 of about $5 \%$ due to LULC change. Highest losses were recorded in Harari (30 \%), Addis Ababa (24\%), Dire Dawa (23\%), and Tigray 
Table 14.7 The total economic value (TEV) of land ecosystem services in Ethiopia

\begin{tabular}{l|c|c|c}
\hline Region & TEV 2001 (million USD) & TEV 2009 (million USD) & Change in TEV (\%) \\
\hline Addis Ababa & 72 & 55 & -23.65 \\
\hline Afar & 11,700 & 12,600 & 7.69 \\
\hline Amhara & 34,300 & 33,100 & -3.50 \\
\hline Benshangul & 10,600 & 10,400 & -1.89 \\
\hline Dire Dawa & 240 & 185 & -22.92 \\
\hline Gambela & 6090 & 5620 & -7.72 \\
\hline Harari & $<1$ & 69 & -29.35 \\
\hline Oromia & 73,800 & 68,400 & -7.32 \\
\hline Somali & 49,200 & 48,200 & -2.03 \\
\hline Southern & 28,500 & 26,800 & -5.96 \\
\hline Tigray & 11,000 & 9730 & -11.55 \\
\hline Total & 226,000 & 215,000 & -4.87 \\
\hline
\end{tabular}

Source Calculated based on Nkonya et al. (2014), using MODIS data

$(12 \%)$ regions. It is notable that increase in TEV was reported in one region-Afar region by about $8 \%$.

\section{Cost of Land Degradation}

\section{Cost of Land Degradation Due to Land Use Cover Change (LUCC)}

The total terrestrial ecosystem value and the loss of ecosystems values due to land use and cover change (LUCC) are reported in Table 14.8. The total TEV for Ethiopia in 2007 is estimated at US\$206 billion (based on the constant 2007 USD values). The GDP value for Ethiopia was US\$19 billion in 2007. Similarly, based on TEV framework, the total cost of land degradation due to LUCC in Ethiopia was $\$ 35$ billion (based on the constant 2007 USD values); translating to annual costs of about $\$ 4.3$ billion. When computed as a percentage of GDP and TEV, the average annual costs of land degradation is 22.5 and $2.1 \%$ respectively.

Table 14.8 Terrestrial ecosystem value and cost of land degradation due to LUCC

\begin{tabular}{l|l|l|l|l}
\hline GDP & TEV & $\begin{array}{l}\text { Costs of land degradation due to } \\
\text { LUCC for the period of 2001-2009 }\end{array}$ & $\begin{array}{l}\text { Cost of LD as } \\
\% \text { of 2007 } \\
\text { GDP }\end{array}$ & $\begin{array}{l}\text { Cost of LD as } \\
\% \text { of TEV of } \\
\text { ES }\end{array}$ \\
\hline US\$ billion & 2007 & $22.5 \%$ & $2.1 \%$ \\
\hline 19.3 & 206 & 34.8 & & $2.5 \%$
\end{tabular}

Source TEV and Land Degradation—Authors' compilation; GDP—World Bank data 


\section{Cost of Land Degradation Due to Use of Land Degrading Practices}

Table 14.9 shows the simulated results of rain-fed maize yield under business-as-usual (BAU) and ISFM scenarios for a period of forty years. Results further show that average maize yield are higher under ISFM-2.8 tons/ha (baseline) and 2.4 tons/ha (end-line) as compared with the BAU scenario- 2.4 tons/ha (baseline) and 1.8 tons/ha (end-line) periods. However, there is a yield decline between the end-line and baseline periods for both ISFM and BAU scenarios. Under ISFM, yield end-line yield declined by about $13 \%$ while under BAU scenario, yield declined by about $25 \%$. Overall, the yield decline due to use of land management practices in maize plots is about $36 \%$. Similarly, simulation analysis show that the yield of wheat declined by about $25 \%$ due to use of land degrading management practices on rain-fed wheat as compared to yield in the previous 30 years. Under ISFM, yield declined by about $8 \%$ while under BAU yield declined by about $20 \%$.

The annually cost of land degradation for the two crops is about $\$ 162$ million (or about $2 \%$ of the GDP). Following FAOSTAT (2013) these three cereals (maize, rice and wheat) account for about $40 \%$ of the cropland globally. While assuming similar levels of land degradation is analogous to that happening on the entire cropland, thus the overall cost of land degradation on entire cropland is about $3.8 \%$ of GDP in Ethiopia (Table 14.10).

Table 14.9 Change in maize and wheat yields under BAU and ISFM

\begin{tabular}{|c|c|c|c|c|c|c|c|}
\hline \multirow[t]{3}{*}{ Crop } & \multicolumn{2}{|l|}{ BAU } & \multicolumn{2}{|l|}{ ISFM } & \multicolumn{2}{|c|}{$\begin{array}{l}\text { Yield Change } \\
(\%)\end{array}$} & \multirow[t]{2}{*}{$\begin{array}{l}\text { Change due to land } \\
\text { degradation }\end{array}$} \\
\hline & Baseline & End-line & Baseline & End-line & BAU & ISFM & \\
\hline & \multicolumn{2}{|c|}{ Yield (tons/ha) } & \multicolumn{2}{|c|}{ Yield (tons/ha) } & \multicolumn{3}{|c|}{ Percent } \\
\hline Maize & 2.39 & 1.79 & 2.79 & 2.44 & -25.1 & -12.6 & 36.0 \\
\hline Wheat & 1.67 & 1.33 & 1.80 & 1.66 & -20.4 & -7.9 & 24.7 \\
\hline
\end{tabular}

Source Authors' compilation

Table 14.10 Cost of soil fertility mining on maize, rice and wheat cropland in Ethiopia

\begin{tabular}{l|l|l}
\hline $\begin{array}{l}\text { Cost of land degradation (soil fertility } \\
\text { mining) }\end{array}$ & $\begin{array}{l}\text { Cost as \% of } \\
\text { GDP }\end{array}$ & $\begin{array}{l}\text { Cost of cropland degradation as } \\
\% \text { GDP }\end{array}$ \\
\hline 2007 US\$ million & $(\%)$ & $(\%)$ \\
\hline 305 & 1.58 & 3.75 \\
\hline
\end{tabular}

Source Authors' compilation 


\section{Cost of Loss of Milk and Meat Production Due to Land Degradation in Grazing Lands}

Table 14.11 shows the simulated results of costs of loss of milk, meat, and costs associated with weight loss of animals not slaughtered or sold associated with land degradation in grazing biomass. Chapter 8 of this volume presents a comprehensive approach to modelling these costs. The results shows that land degradation in rangelands had a negligible effect on milk and meat production. The total annual costs of milk and meat production losses were about \$38 million and \$2.4 million respectively. The bigger proportion of milk and meat losses is experienced in warm semi-arid ( $\$ 10.8$ million), and warm sub-humid ( $\$ 8.5$ million). The total annual gross loss was about $\$ 52$ million. The bigger proportion of the total gross losses is consequently experienced in warm semi-arid ( $\$ 14$ million), warm sub-humid ( $\$ 11.2$ million) and cool sub-humid (\$10.4 million) agro-ecologies.

\section{Cost of Action and Inaction Against Land Degradation Due to LUCC}

Results of the assessment of the costs of action against land degradation which help in determining whether the action against land degradation could be justified economically are presented in Table 14.12. As Nkonya et al. (2013) note, an action against land degradation will be taken if the cost of inaction is greater than the cost

Table 14.11 Cost of milk and meat production loss due to degradation of rangelands

\begin{tabular}{|c|c|c|c|c|}
\hline \multirow[t]{2}{*}{$\begin{array}{l}\text { Agro-ecological } \\
\text { zones }\end{array}$} & Milk & Meat & $\begin{array}{l}\text { Total loss } \\
\text { (Milk and Meat) }\end{array}$ & $\begin{array}{l}\text { Total gross loss-includes weight loss } \\
\text { of animals not slaughtered }\end{array}$ \\
\hline & \multicolumn{4}{|c|}{2007 US\$ million } \\
\hline $\begin{array}{l}\text { Tropic-cool } \\
\text { semi-arid }\end{array}$ & 4.535 & 0.338 & 4.873 & 6.194 \\
\hline Tropic-cool arid & 0.003 & 0.003 & 0.006 & 0.004 \\
\hline $\begin{array}{l}\text { Tropic-cool } \\
\text { humid }\end{array}$ & 0.145 & 0.005 & 0.150 & 0.198 \\
\hline $\begin{array}{l}\text { Tropic-cool } \\
\text { sub-humid }\end{array}$ & 7.640 & 0.315 & 7.945 & 10.435 \\
\hline $\begin{array}{l}\text { Tropic-warm } \\
\text { semi-arid }\end{array}$ & 10.262 & 0.507 & 10.769 & 14.016 \\
\hline $\begin{array}{l}\text { Tropic-warm } \\
\text { arid }\end{array}$ & 7.087 & 0.922 & 8.009 & 9.680 \\
\hline $\begin{array}{l}\text { Tropic-warm } \\
\text { sub-humid }\end{array}$ & 8.177 & 0.327 & 8.504 & 11.168 \\
\hline Total & 37.849 & 2.417 & 40.266 & 51.696 \\
\hline
\end{tabular}

Source Authors' compilation 


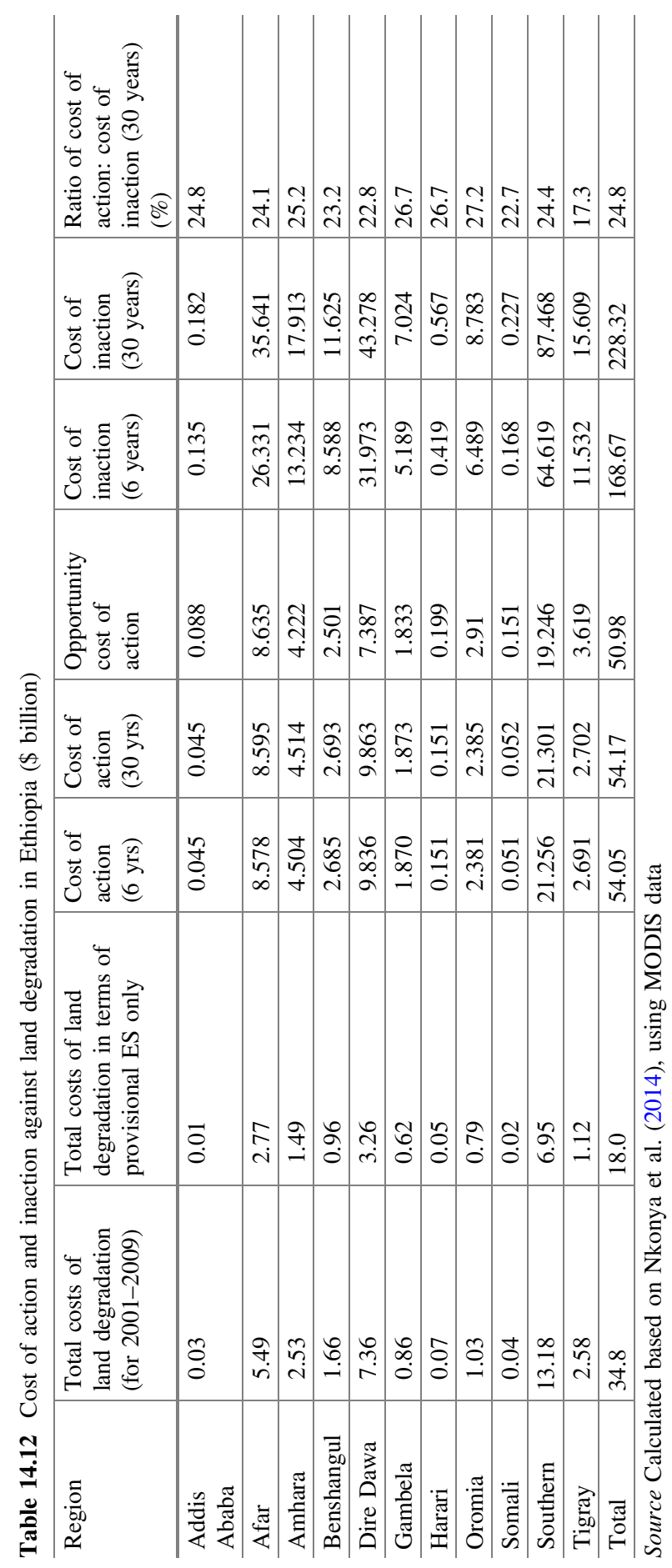




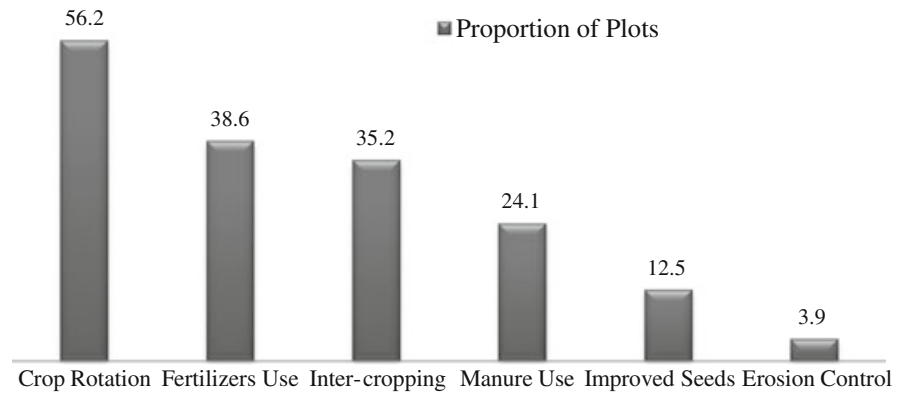

Fig. 14.2 The type of SLM technologies adopted in Ethiopia. Source Kirui (in press) unpublished Ph.D. thesis

of taking action. The total cost of land degradation is about 34 billion USD (translating to about 4.3 billion USD annually). Half (51\%) of this cost, or $\$ 18$ billion of this cost represent the loss of provisional ecosystem services. The other (about $49 \%$ ) represents the supporting and regulatory and cultural ecosystem services.

In a 6-year period, the total cost of action to about $\$ 54$ billion while the cost of inaction summed to about $\$ 169$ billion. In a 30-year horizon, the costs of action were about $\$ 54$ billion. However, the cost of inaction (if nothing is done to address land degradation) the resulting losses may equal almost $\$ 228$ billion during the same period. The implications is that, the costs of action against land degradation are lower than the costs of inaction by about 4.4 times over the 30 year horizon; i.e. the ratio of action to cost of inaction is $24 \%$. This implies that each dollar spent on addressing land degradation is likely to have about 4.4 dollars of returns.

\section{Adoption of SLM Practices/Technologies in Ethiopia}

Based on farmers' responses, six SLM practices were considered including crop rotation, intercropping, improved seeds, ${ }^{1}$ use of manure, use of chemical fertilizers, and soil erosion control (such as soil bunds, stone bunds, gabions, grass strips, terraces among others) were selected as major SLM technologies/practices adopted by small farmers in Ethiopia.

As shown in Fig. 14.2 below crop rotation, chemical fertilizer use and inter-cropping are the most common SLM practices adopted by most farmers. Crop rotation was practiced in about $56 \%$ of the plots while fertilizer was used in about $39 \%$ of the plots (Fig. 14.2).

\footnotetext{
${ }^{1}$ We consider improved seeds as SLM technology following the definition by Liniger (2011) and Liniger et al. (2011). The adoption of a new technology, such as improved seeds, is usually a choice between traditional and new technology. Farmers' decision to adopt or not to adopt is, thus, based on the profitability of the technology.
} 
Table 14.13 Number of SLM technologies/practices adopted

\begin{tabular}{l|l}
\hline $\begin{array}{l}\text { Number of SLM technologies applied } \\
\text { (on a given plot) }\end{array}$ & $\begin{array}{l}\text { Proportion of plots } \\
\text { (where the technology applied) }\end{array}$ \\
\hline 0 & 14.8 \\
\hline 1 & 33.5 \\
\hline 2 & 26.8 \\
\hline 3 & 17.2 \\
\hline 4 & 7.1 \\
\hline 6 & 0.7 \\
\hline
\end{tabular}

Source Kirui (in press) unpublished Ph.D. thesis

We present the distribution of the number of SLM practices/technologies used in farm plots in Table 14.13. The distribution ranged from 0 to 6 . About $15 \%$ of the surveyed households did not apply any SLM technologies in their farm plots. Further, our assessments show that only one SLM technology was used in about $33 \%$ of the plots. Similarly, two SLM technologies were applied in about $27 \%$ of the plots. Fewer plots applied more than two SLM technologies simultaneously in one plot. In total, about 17 and $7 \%$ of the plots applied three and four SLM technologies in one plot in the region. Very few plots applied five SLM technologies $(0.7 \%)$ (Table 14.13$)$.

\section{Determinants of SLM Adoption: Logit Model}

The results of the Logit regression model on the determinants of adoption of SLM technologies are presented in Table 14.14. An adopter was defined as an individual using at least one SLM technology. The assessment is done at plot level. The model fit the data well; it is statistically significant at $1 \%$ with a log likelihood ratio $\left(\mathrm{Chi}^{2}\right.$ (30)) of 1649 and Pseudo $\mathrm{R}^{2}=0.1387$ (Table 14.14).

The proximate factors that significantly determine the likelihood of adopting SLM technology include temperature, rainfall, and agro-ecological zonal characteristics. Both rainfall and temperature positively influence the probability of using SLM technologies. However, plots located in warm humid/sub-humid, cool arid semi-arid agro-ecological zones or cool humid/sub-humid are less likely to adopt SLM technologies compared to those located in warm arid/semi-arid agro-ecology.

The adoption of SLM technologies is also significantly influenced by household-level variables such as age, gender and education level of the household head, and family size. Age variable is positively significant while age squared was negatively significant indicating that adoption increase with age but at a decreasing rate. Male-headed households are also more likely to adopt SLM technologies compared to their counterparts. Education and the abundance of labor supply through larger bigger family size positively influence the adoption of SLM technologies. 
Table 14.14 Drivers of adoption and number of SLM adopted: logit and poisson results

\begin{tabular}{|c|c|c|c|c|}
\hline \multirow[t]{2}{*}{ Variable } & \multicolumn{2}{|l|}{ Logit } & \multicolumn{2}{|l|}{ Poisson } \\
\hline & Coefficient & Std. Err. & Coefficient & Std. Err. \\
\hline Annual mean temperature $\left({ }^{\circ} \mathrm{C}\right)$ & $0.134 * * *$ & 0.013 & $0.024 * * *$ & 0.004 \\
\hline Annual mean temperature square & $-0.000 * * *$ & 0.000 & $-0.000 * * *$ & 0.000 \\
\hline Annual mean rainfall $(\mathrm{mm})$ & $0.005 * * *$ & 0.001 & $0.001 * * *$ & 0.000 \\
\hline Annual mean rainfall square & $-0.000 * * *$ & 0.000 & $-0.000 * * *$ & 0.000 \\
\hline Temperature $\times$ rainfall & 0.000 & 0.000 & $0.000 * * *$ & 0.000 \\
\hline Elevation (meters above sea level) & 0.000 & 0.000 & $0.000 * * *$ & 0.000 \\
\hline AEZ (1 = warm humid/sub-humid, $0=$ No) & $-0.648 * * *$ & 0.250 & $-0.159 *$ & 0.089 \\
\hline AEZ $(1=$ cool arid $/$ semiarid, $0=$ No $)$ & $-1.094 * * *$ & 0.201 & $-0.126^{*}$ & 0.068 \\
\hline AEZ $(1=$ cool humid/sub-humid, $0=$ No $)$ & $-0.663 * * *$ & 0.228 & -0.006 & 0.075 \\
\hline Age of household head (years) & $0.027 * * *$ & 0.010 & 0.002 & 0.003 \\
\hline Age of household head square & $-0.000 * * *$ & 0.000 & 0.000 & 0.000 \\
\hline Gender of household head $(1=$ Male, $0=$ No $)$ & $0.189 * * *$ & 0.071 & -0.002 & 0.019 \\
\hline Years of education of household head & -0.025 & 0.023 & $0.011^{*}$ & 0.006 \\
\hline Size of household (adult equivalent) & $0.036 * * *$ & 0.014 & $0.018 * * *$ & 0.003 \\
\hline Slope of the plot & $0.083 * *$ & 0.039 & -0.003 & 0.010 \\
\hline Land tenure status of the plot & -0.063 & 0.061 & $0.033^{* *}$ & 0.014 \\
\hline Size of the plot (ha) & 0.008 & 0.038 & $-0.017 *$ & 0.009 \\
\hline Access to extension $(1=$ Yes, $0=\mathrm{No})$ & $1.039 * * *$ & 0.080 & $0.189 * * *$ & 0.015 \\
\hline Distance to plot from home $(\mathrm{km})$ & 0.000 & 0.000 & 0.000 & 0.000 \\
\hline Distance from plot to market $(\mathrm{km})$ & $-0.014 * * *$ & 0.002 & $-0.003 * * *$ & 0.001 \\
\hline Membership farmer groups $(1=$ Yes $0=$ No $)$ & 0.070 & 0.072 & 0.007 & 0.016 \\
\hline Access to credit $(1=$ Yes, $0=\mathrm{No})$ & $0.160 * *$ & 0.064 & $0.027 *$ & 0.015 \\
\hline Amount of credit accessed (USD) & 0.000 & 0.000 & $0.000 *$ & 0.000 \\
\hline Value of household assets (USD) & 0.000 & 0.000 & 0.000 & 0.000 \\
\hline Use of irrigation $(1=$ Yes, $0=\mathrm{No})$ & $0.971 * * *$ & 0.153 & $0.380 * * *$ & 0.034 \\
\hline Constant & -5.49 & 4.836 & $3.77 * * *$ & 1.294 \\
\hline \multirow[t]{4}{*}{ Model characteristics } & \multicolumn{2}{|c|}{ No. of obs. $=14,170$} & \multicolumn{2}{|c|}{ No. of obs. $=14,170$} \\
\hline & \multicolumn{2}{|c|}{$\operatorname{LR~Chi}^{2}(30)=1649$} & \multicolumn{2}{|c|}{$\operatorname{LR~Chi}^{2}(30)=1537$} \\
\hline & \multicolumn{2}{|c|}{ Prob $>$ chi $^{2}=0.000$} & \multicolumn{2}{|c|}{ Prob $>\mathrm{chi}^{2}=0.000$} \\
\hline & \multicolumn{2}{|c|}{ Pseudo $\mathrm{R}^{2}=0.1837$} & \multicolumn{2}{|c|}{ Pseudo $\mathrm{R}^{2}=0.135$} \\
\hline
\end{tabular}

$* * *, * *$, and *Denotes significance at 1,5 and $10 \%$ respectively

Source Kirui (in press) unpublished Ph.D. thesis

The effect of plot level characteristics on the adoption of SLM technologies is also evident in our analysis. Steeper slopes have a positive relationship with the adoption of SLM technologies. Similarly access to extension services positively influence the adoption of SLM technologies. Market access also acts as a significant determinant of SLM technologies. This is shown by the negative significant relationship between the distance from the plot to the market and the adoption of SLM 
technologies. The number of SLM technologies adopted is also significantly incentivized by such socio economic variables such as access to credit and the household per capita expenditure. While access to credit positively influences the adoption of SLM technologies, the relationship between household per capita expenditure and adoption of SLM technologies is however negative.

\section{Determinants of Number of SLM Practices Adopted: Poisson Regression}

The results of the Poisson regression on the determinants of the number of SLM technologies used by households are also presented in Table 14.14. The assessment is also done at plot level. The model fits the data well-it is statistically significant at $1 \%$ with a $\log$ likelihood ratio $\left(\mathrm{Chi}^{2}(30)\right)$ of 1537 and Pseudo $\mathrm{R}^{2}=0.305$. There was no evidence of dispersion (over-dispersion and under-dispersion). We estimated the corresponding negative binomial regressions and all the likelihood ratio tests (comparing the negative binomial model to the Poisson model) were not statistically significant - suggesting that the Poisson model was best fit for our study objective. Results show that several proximate and underlying factors significantly determine the number of SLM technologies adopted (Table 14.14).

Among the proximate biophysical factors that significantly determine the number of SLM adopted include temperature, rainfall elevation, latitude and longitude positions, and agro-ecological zonal characteristics. The relationships between these factors and number of SLM technologies adopted are mixed. For example, the proximate biophysical factors that positively influence the number of SLM technologies adopted include temperature, rainfall and elevation. However, being in warm humid/sub-humid or in cool arid semi-arid agro-ecological zones (as compared to warm arid/semi-arid) has a negative significant influence on the number of SLM technologies adopted. The number of SLM technologies adopted has a negative relationship with latitude and longitude but a positive relationship with the interaction of latitude and longitude.

Among the household-level variables, only education level of the household head and family size were significant in influencing the number of technologies adopted. Education and the abundance of labor supply through larger bigger family size positively influence the adoption of more SLM technologies.

We also assessed the effect of plot level characteristics on the number of SLM technologies adopted. The ownership of land title (deed) is an incentive to investment on several SLM technologies. Similarly access to extension services positively influence the adoption of several SLM technologies.

Market access also acts as a significant determinant of the number of SLM technologies. The farther away from the market, the less the number of SLM technologies adopted. We also find a negative significant effect between the size of the farm and the number of SLM technologies used. The number of SLM 
technologies adopted is also significantly incentivized by such socio-economic variables such as access to and amount of credit accessed.

\section{Local and Community-Level Initiatives to Address Land Degradation in Ethiopia}

The actions that the communities take to address loss of ecosystem services or enhance or maintain ecosystem services improvement are presented in Table 14.15. For example, afforestation is one key action taken to address loss of forests' ecosystem services and to enhance ecosystem services improvement within forest ecosystems in Kemona, Ifabas, Jogo and Garambabo communities. To further curtail deforestation, area closures and stricter enforcement of existing bylaws and enacting new laws were some of the approaches taken by local communities in Kemona, Ifabas and Koka Negewo. The bylaws constitute community sanctions and fines and imprisonment with the help of government law enforcement agencies.

The most common approach applied to maintain or address the deterioration in the quality of cropland was soil fertility management (use organic and inorganic fertilizer). Other SLM practices such as crop rotation and use of soil and water conservation measures (such as crop and fallow rotations, soil and stone bunds, and terracing).

Likewise, area closure, controlled grazing and community sanctions for overgrazing were the most common approaches used to maintain the quality and address decline in grassland ecosystem service values. Area closures (zoning)-when

Table 14.15 Actions taken to maintain and/or address the loss of ecosystem services

\begin{tabular}{|c|c|c|c|c|}
\hline District & Village & Actions in cropland & Actions in forest & Actions in grassland \\
\hline $\begin{array}{l}\text { Guba } \\
\text { Goricha }\end{array}$ & Kemona & $\begin{array}{l}\text { Fertilizer, } \\
\text { composting, soil and } \\
\text { stone bands }\end{array}$ & $\begin{array}{l}\text { Afforestation, } \\
\text { protection of the } \\
\text { existing forest }\end{array}$ & $\begin{array}{l}\text { Area closures Soil } \\
\text { and stone bunds, } \\
\text { planting of trees }\end{array}$ \\
\hline Tulo & Ifabas & $\begin{array}{l}\text { Fertilizer, compost, } \\
\text { soil and stone bands, } \\
\text { terracing }\end{array}$ & $\begin{array}{l}\text { Area closure, } \\
\text { afforestation, } \\
\text { watershed } \\
\text { management }\end{array}$ & None \\
\hline Becho & $\begin{array}{l}\text { Mande } \\
\text { Tufisa }\end{array}$ & $\begin{array}{l}\text { Fertilizer, } \\
\text { composting }\end{array}$ & None & $\begin{array}{l}\text { Terracing, stone and } \\
\text { soil bunds }\end{array}$ \\
\hline Lume & Jogo & $\begin{array}{l}\text { Fertilizer, soil and } \\
\text { stone bunds }\end{array}$ & Afforestation & Area closures \\
\hline Nonsebo & Gara-mbabo & None & $\begin{array}{l}\text { Afforestation, } \\
\text { watershed } \\
\text { management }\end{array}$ & $\begin{array}{l}\text { Water and soil } \\
\text { conservation }\end{array}$ \\
\hline Lume & $\begin{array}{l}\text { Koka } \\
\text { Negewo }\end{array}$ & $\begin{array}{l}\text { Fertilizer, } \\
\text { composting, crop } \\
\text { rotation }\end{array}$ & Protected forests & None \\
\hline
\end{tabular}

Source Kirui (in press) unpublished Ph.D. thesis 
accompanied by community bylaws to sanction and punish offenders-were a particularly successful way to address degraded community grasslands.

\section{Conclusions}

The solutions to land degradation need to be based on through addressing their local drivers. Better understanding of households' behavior about land management as well as policy and institutional factors that affect such decisions are crucial, but usually underestimated in most measures to address land degradation in Ethiopia.

Many forms of land degradation occur in Ethiopia: water and wind erosion; salinization and acidification, and both physical and biological degradation of soils. More than $85 \%$ of the land in Ethiopia is estimated to be moderately to very severely degraded, and about $75 \%$ is affected by desertification. Recent estimates using satellite imagery show that land degradation hotspots over the last three decades cover about $23 \%$ of land area in Ethiopia.

The analysis of nationally representative household surveys shows that the key drivers of SLM in Ethiopia are biophysical, demographic, regional and socio-economic determinants. Access to agricultural extension services, secure land tenure as proxied by ownership of land title deed and market access are important incentives to the adoption of SLM and the number of SLM technologies adopted. Thus, policies and strategies relating to securing tenure rights, building the capacity of land users through access to extension services, and access to financial and physical assets may incentivize SLM uptake. The local institutions to manage grazing lands and forests through collective action need to be encouraged.

The total value of land ecosystem services for Ethiopia is estimated to be about US $\$ 206$ billion. The annual cost of land degradation is about $\$ 4.3$ billion. Only about $\$ 2.2$ billion $(51 \%)$ of this cost of land degradation represent the provisional ecosystem services. The other (49\%) represents the supporting and regulatory and cultural ecosystem services. Use of land degrading practices in croplands (maize and wheat) was estimated to result in losses amounting to US\$162 million-representing $2 \%$ of GDP. The costs of land degradation on static grazing land (loss of milk, meat and the cost of weight loss of animals not slaughtered or sold) were estimated to amount to $\$ 52$ million.

The costs of action to rehabilitate lands degraded between 2001 and 2009 due to land use and land cover change were found to equal about US\$54 billion over a 30 -year horizon, whereas if nothing is done, the resulting losses may equal almost US\$228 billion during the same period. This implies that the costs of action against land degradation are lower than the costs of inaction by about 4.4 times over the 30 year horizon; i.e. the ratio of action to cost of inaction is $23 \%$. This implies that each dollar spent on rehabilitating degraded lands in Ethiopia may return about 4.4 dollars. 
Open Access This chapter is distributed under the terms of the Creative Commons Attribution Noncommercial License, which permits any noncommercial use, distribution, and reproduction in any medium, provided the original author(s) and source are credited.

\section{Annex}

See Tables A.1, A.2 and A.3.

Table A.1 Land use land cover classification in Ethiopia in 2001 (million ha)

\begin{tabular}{l|l|l|l|l|l|l|l|l}
\hline Region & Cropland & Forest & Grassland & Shrublands & Woodland & Urban & Barren & Water \\
\hline Addis Ababa & 0.014 & 0.003 & 0.009 & 0.002 & 0.010 & 0.017 & - & - \\
\hline Afar & 0.482 & 0.009 & 1.444 & 3.557 & 0.226 & 0.001 & 3.935 & 0.063 \\
\hline Amhara & 3.067 & 0.195 & 7.272 & 0.632 & 4.085 & 0.008 & 0.009 & 0.298 \\
\hline Benshangul & 0.044 & 0.058 & 1.968 & 0.000 & 2.894 & 0.001 & - & - \\
\hline Dire Dawa & 0.004 & 0.000 & 0.061 & 0.037 & 0.002 & 0.002 & - & - \\
\hline Gambela & 0.014 & 0.230 & 0.930 & 0.000 & 1.378 & 0.000 & 0.000 & 0.001 \\
\hline Harari & 0.001 & 0.002 & 0.027 & 0.006 & 0.001 & 0.000 & - & - \\
\hline Oromia & 3.041 & 3.011 & 9.829 & 7.144 & 9.077 & 0.032 & 0.102 & 0.188 \\
\hline Somali & 0.050 & 0.007 & 1.082 & 28.700 & 0.082 & 0.004 & 1.535 & - \\
\hline Southern & 1.192 & 1.905 & 3.237 & 0.590 & 4.159 & 0.005 & 0.063 & 0.086 \\
\hline Tigray & 0.597 & 0.063 & 2.676 & 1.130 & 0.466 & 0.002 & 0.008 & 0.001 \\
\hline Total & 8.51 & 5.49 & 28.50 & 41.80 & 22.40 & 0.07 & 5.65 & 0.64 \\
\hline
\end{tabular}

Source Calculated based on Nkonya et al. (2014), using MODIS data

Table A.2 Land use land cover classification in Ethiopia in 2009 (million ha)

\begin{tabular}{l|c|l|l|l|l|l|l|l}
\hline Region & Cropland & Forest & Grassland & Shrublands & Woodland & Urban & Barren & Water \\
\hline Addis Ababa & 0.021 & 0.001 & 0.008 & 0.004 & 0.004 & 0.017 & - & - \\
\hline Afar & 0.307 & 0.009 & 1.105 & 5.153 & 0.050 & 0.001 & 3.048 & 0.045 \\
\hline Amhara & 4.719 & 0.053 & 7.742 & 0.590 & 2.155 & 0.008 & 0.009 & 0.291 \\
\hline Benshangul & 0.016 & 0.006 & 1.943 & 0.001 & 2.999 & 0.001 & - & - \\
\hline Dire Dawa & 0.004 & - & 0.018 & 0.080 & 0.002 & 0.002 & - & - \\
\hline Gambela & 0.027 & 0.303 & 0.368 & 0.002 & 1.851 & 0.000 & 0.000 & 0.001 \\
\hline Harari & 0.012 & 0.000 & 0.015 & 0.010 & 0.000 & 0.000 & - & - \\
\hline Oromia & 3.692 & 2.094 & 8.731 & 7.299 & 10.300 & 0.032 & 0.100 & 0.173 \\
\hline Somali & 0.035 & 0.001 & 0.587 & 29.000 & 0.069 & 0.004 & 1.768 & - \\
\hline Southern & 1.573 & 1.602 & 2.966 & 0.593 & 4.400 & 0.005 & 0.026 & 0.076 \\
\hline Tigray & 0.883 & 0.003 & 2.015 & 1.826 & 0.207 & 0.002 & 0.006 & 0.001 \\
\hline Total & 11.30 & 4.07 & 25.50 & 44.60 & 22.00 & 0.07 & 4.96 & 0.59 \\
\hline Source Cal & & & & & & & &
\end{tabular}

Source Calculated based on Nkonya et al. (2014), using MODIS data 
Table A.3 Major issues and priority areas in combating land degradation and poverty

\begin{tabular}{|c|c|c|c|c|}
\hline $\begin{array}{l}\text { Important } \\
\text { issues/factors }\end{array}$ & $\begin{array}{l}\text { Main problems; why it is } \\
\text { an issue? }\end{array}$ & $\begin{array}{l}\text { Desired } \\
\text { situation } \\
\text { (objective, aim) }\end{array}$ & $\begin{array}{l}\text { Measures to be } \\
\text { taken (strategy) }\end{array}$ & $\begin{array}{l}\text { Responsible } \\
\text { body }\end{array}$ \\
\hline Participation & $\begin{array}{l}\text { Lack of an enabling } \\
\text { environment } \\
\text { Lack of awareness } \\
\text { Misconception of } \\
\text { partnership }\end{array}$ & $\begin{array}{l}\text { Enhancing } \\
\text { enabling } \\
\text { environment } \\
\text { - Enhancing } \\
\text { partnership } \\
\text { - Devolution of } \\
\text { power }\end{array}$ & $\begin{array}{l}\text { Awareness } \\
\text { creation } \\
\text { Clear definition of } \\
\text { partnership } \\
\text { Empower local } \\
\text { governance }\end{array}$ & $\begin{array}{l}\text { GOs, NGOs, } \\
\text { International } \\
\text { partners }\end{array}$ \\
\hline Land tenure & Insecurity of tenure & $\begin{array}{l}\text { Ensure long } \\
\text { term use } \\
\text { through issuing } \\
\text { a sort of title } \\
\text { deed }\end{array}$ & $\begin{array}{l}\text { Proper land use } \\
\text { policy and } \\
\text { legislation } \\
\text { Promote proper } \\
\text { indigenous } \\
\text { practices }\end{array}$ & $\begin{array}{l}\text { Federal and } \\
\text { regional } \\
\text { governments }\end{array}$ \\
\hline $\begin{array}{l}\text { Inappropriate } \\
\text { land use } \\
\text { system }\end{array}$ & $\begin{array}{l}\text { Steep slope farming } \\
\text { Deforestation } \\
\text { No or short fallowing } \\
\text { period } \\
\text { Lack of modern } \\
\text { technologies } \\
\text { Lack of know-how } \\
\text { Overgrazing } \\
\text { Population pressure }\end{array}$ & $\begin{array}{l}\text { In place land } \\
\text { use and } \\
\text { ownership } \\
\text { policy } \\
\text { Forest policy } \\
\text { Availability of } \\
\text { modern } \\
\text { know-how and } \\
\text { technology } \\
\text { Grazing } \\
\text { management } \\
\text { policy and } \\
\text { legislation } \\
\text { population } \\
\text { policy (in } \\
\text { place) }\end{array}$ & $\begin{array}{l}\text { Issues appropriate } \\
\text { policies and } \\
\text { legislation on land } \\
\text { use, forest, SWC } \\
\text { and grazing } \\
\text { management } \\
\text { Educate the public } \\
\text { Implement } \\
\text { population policy } \\
\text { Make available } \\
\text { modern } \\
\text { technology } \\
\text { through research }\end{array}$ & $\begin{array}{l}\text { Federal and } \\
\text { regional } \\
\text { governments } \\
\text { NGOs/CBOs } \\
\text { development } \\
\text { partners }\end{array}$ \\
\hline $\begin{array}{l}\text { Livestock } \\
\text { population }\end{array}$ & $\begin{array}{l}\text { Overgrazing/uncontrolled } \\
\text { grazing } \\
\text { Quantity valued than } \\
\text { quality }\end{array}$ & $\begin{array}{l}\text { Livestock } \\
\text { number } \\
\text { balanced to the } \\
\text { available feed } \\
\text { resources }\end{array}$ & $\begin{array}{l}\text { Increase off-take } \\
\text { rate } \\
\text { Change the mgt } \\
\text { system from open } \\
\text { to zero grazing }\end{array}$ & $\begin{array}{l}\text { Govt's, } \\
\text { NGOs/CBOs, } \\
\text { communities }\end{array}$ \\
\hline $\begin{array}{l}\text { Population } \\
\text { pressure }\end{array}$ & $\begin{array}{l}\text { Man to land ratio } \\
\text { incompatible } \\
\text { Uncontrolled growth } \\
\text { Women not educated and } \\
\text { empowered to control } \\
\text { their own fertility }\end{array}$ & $\begin{array}{l}\text { Population } \\
\text { growth } \\
\text { balanced to } \\
\text { economic } \\
\text { growth } \\
\text { Family } \\
\text { planning } \\
\text { exercised } \\
\text { Women } \\
\text { empowered }\end{array}$ & $\begin{array}{l}\text { Proper } \\
\text { implementation of } \\
\text { the population } \\
\text { policy (family } \\
\text { planning) } \\
\text { Alternative } \\
\text { employment } \\
\text { opportunity } \\
\text { created } \\
\text { Resettlement } \\
\text { Educate and } \\
\text { empower women }\end{array}$ & $\begin{array}{l}\text { Governments } \\
\text { NGOs/CBOs } \\
\text { Development } \\
\text { partners }\end{array}$ \\
\hline
\end{tabular}


Table A.3 (continued)

\begin{tabular}{|c|c|c|c|c|}
\hline $\begin{array}{l}\text { Important } \\
\text { issues/factors }\end{array}$ & $\begin{array}{l}\text { Main problems; why it is } \\
\text { an issue? }\end{array}$ & $\begin{array}{l}\text { Desired } \\
\text { situation } \\
\text { (objective, aim) }\end{array}$ & $\begin{array}{l}\text { Measures to be } \\
\text { taken (strategy) }\end{array}$ & $\begin{array}{l}\text { Responsible } \\
\text { body }\end{array}$ \\
\hline Poverty & $\begin{array}{l}\text { Unbalanced population } \\
\text { growth vis-à-vis economic } \\
\text { growth } \\
\text { High unemployment rate } \\
\text { Low productivity } \\
\text { (land/man) } \\
\text { Lack of poverty reduction } \\
\text { strategy } \\
\text { Inequitable share and } \\
\text { distribution of resources } \\
\text { and services } \\
\text { Hunger, illiteracy, etc. } \\
\text { Deprivation of basic needs } \\
\text { (food, shelter, cloth) }\end{array}$ & $\begin{array}{l}\text { Economic } \\
\text { growth } \\
\text { balanced to } \\
\text { population } \\
\text { growth } \\
\text { Access to basic } \\
\text { needs } \\
\text { Access to } \\
\text { social services } \\
\text { Equitable } \\
\text { sharing and } \\
\text { distribution to } \\
\text { resources and } \\
\text { services }\end{array}$ & $\begin{array}{l}\text { Integrate economic } \\
\text { development with } \\
\text { population } \\
\text { controlled strategy } \\
\text { Encourage labor } \\
\text { intensive } \\
\text { investment } \\
\text { Improve the } \\
\text { quality of the } \\
\text { population through } \\
\text { education, } \\
\text { knowledge and } \\
\text { skill } \\
\text { Promote equitable } \\
\text { share and } \\
\text { distribution of } \\
\text { resources and } \\
\text { services }\end{array}$ & $\begin{array}{l}\text { Governments } \\
\text { NGOs/CBOs } \\
\text { Development } \\
\text { partners } \\
\text { Population }\end{array}$ \\
\hline $\begin{array}{l}\text { Institutional } \\
\text { failures }\end{array}$ & $\begin{array}{l}\text { Institutional instability } \\
\text { Overlapping of mandates } \\
\text { Shortage resources } \\
\text { Integration and } \\
\text { coordination problem } \\
\text { Lack of a common forum }\end{array}$ & $\begin{array}{l}\text { Stable with } \\
\text { clear mandates } \\
\text { institutions } \\
\text { Adequate } \\
\text { resources } \\
\text { Clear } \\
\text { mechanism of } \\
\text { integration and } \\
\text { coordination } \\
\text { Established } \\
\text { M\&E }\end{array}$ & $\begin{array}{l}\text { Establish } \\
\text { institution with } \\
\text { clear mandate and } \\
\text { empowerment } \\
\text { Secure appropriate } \\
\text { resources } \\
\text { Create a } \\
\text { mechanism where } \\
\text { institutions } \\
\text { integrate and } \\
\text { coordinate their } \\
\text { activities } \\
\text { Established } \\
\text { MandE }\end{array}$ & $\begin{array}{l}\text { - Federal } \\
\text { Govt's } \\
\text { - Regional } \\
\text { States } \\
\text { - NGOs } \\
- \\
\text { Development } \\
\text { partners }\end{array}$ \\
\hline Investment & $\begin{array}{l}\text { Conflict with NR } \\
\text { conservation measures } \\
\text { Low investment on } \\
\text { off-farm activities }\end{array}$ & $\begin{array}{l}\text { Proper EIA } \\
\text { Labor intensive } \\
\text { investment } \\
\text { promoted }\end{array}$ & $\begin{array}{l}\text { EPA should be } \\
\text { empowered } \\
\text { Labor intensive } \\
\text { investments should } \\
\text { be encouraged }\end{array}$ & $\begin{array}{l}\text { Governments } \\
\text { Private } \\
\text { investors } \\
\text { Development } \\
\text { partners }\end{array}$ \\
\hline
\end{tabular}


Table A.3 (continued)

\begin{tabular}{|c|c|c|c|c|}
\hline $\begin{array}{l}\text { Important } \\
\text { issues/factors }\end{array}$ & $\begin{array}{l}\text { Main problems; why it is } \\
\text { an issue? }\end{array}$ & $\begin{array}{l}\text { Desired } \\
\text { situation } \\
\text { (objective, aim) }\end{array}$ & $\begin{array}{l}\text { Measures to be } \\
\text { taken (strategy) }\end{array}$ & $\begin{array}{l}\text { Responsible } \\
\text { body }\end{array}$ \\
\hline $\begin{array}{l}\text { Infrastructure } \\
\text { and market } \\
\text { failures }\end{array}$ & $\begin{array}{l}\text { Lack of access to market } \\
\text { Lack of access to services } \\
\text { (school, light, clinic, water } \\
\text { grinding mill, } \\
\text { communication, extension } \\
\text { and family planning } \\
\text { services }\end{array}$ & $\begin{array}{l}\text { Access to } \\
\text { services } \\
\text { Access to } \\
\text { markets }\end{array}$ & $\begin{array}{l}\text { Improve rural } \\
\text { infrastructure and } \\
\text { services } \\
\text { Promote } \\
\text { appropriate energy } \\
\text { saving technology } \\
\text { Develop } \\
\text { alternative } \\
\text { renewable energy } \\
\text { system }\end{array}$ & $\begin{array}{l}\text { Federal and } \\
\text { Regional } \\
\text { Governments } \\
\text { NGOs/CBOs } \\
\text { Development } \\
\text { partners }\end{array}$ \\
\hline
\end{tabular}

Source MeKonen (2002) (cited by Berry 2003)

\section{References}

Bai, Z. G., Dent, D. L., Olsson, L., \& Schaepman, M. E. (2008). Global assessment of land degradation and improvement. 1. Identification by remote sensing. Wageningen, The Netherlands: International Soil Reference and Information Centre (ISRIC).

Barbier, E. B. (1989). Sustaining agriculture on marginal land: A policy framework. Environment Science and Policy for Sustainable Development, 31(9), 12-40.

Barbier, E. B. (2000). The economic linkages between rural poverty and land degradation: Some evidence from Africa. Agriculture, Ecosystems \& Environment, 82(1), 355-370.

Belay, K. T., Van Rompaey, A., Poesen, J., Van Bruyssel, S., Deckers, J., \& Amare, K. (2014). Spatial analysis of land cover changes in eastern Tigray (Ethiopia) from 1965 to 2007: Are there signs of a forest transition? Land Degradation and Development. doi:10.1002/ldr.2275

Berry, L. (2003). Land degradation in Ethiopia: Its extent and impact. A study commissioned by the GM with WB support.

Bojö, J., \& Cassells, D. (1995). Land degradation and rehabilitation in Ethiopia: A reassessment. Working Paper No. 17, World Bank, 1995, pp. 36.

CSA. (2013). Agriculture in figures: Key findings of the 2012/2013 (2005 EC) crop year. Ethiopia: Addis Ababa.

Dregne, H. E. (1991). Human activities and soil degradation. Semiarid Lands and Deserts: Soil Resource and Reclamation, 19, 335.

EEPC. (2002). Koka dam sedimentation study: recommendations report. Ethiopian Electric Power Corporation. Ethiopia: Addis Ababa.

Evans, J., \& Geerken, R. (2004). Discrimination between climate and human-induced dryland degradation. Journal of Arid Environments, 57(4), 535-554.

Eyasu, E. (2003). National assessment on environmental roles of agriculture in Ethiopia. Unpublished Research Report Submitted to EEA, Addis Ababa.

FAO. (1986). Highlands reclamation study ethiopia final report (Vol. I \& II). Italy: Rome.

Genanew, B. W., \& Alemu, M. (2012). Investments in land conservation in the Ethiopian highlands: A household plot-level analysis of the roles of poverty, tenure security, and market incentives. International Journal of Economics and Finance, 4(6). URL: http://dx.doi.org/10. 5539/ijef.v4n6p32. Accessed 31 May 2015.

Helldén, U., \& Tottrup, C. (2008). Regional desertification: A global synthesis. Global and Planetary Change, 64(3), 169-176. 
Holden, S., Shiferaw, B., \& Pender, J. (2004). Non-farm income, household welfare, and sustainable land management in a less-favoured area in the Ethiopian highlands. Food Policy, 29, 369-392.

Hurni, H. 1993. Land degradation, famines and resources scenarios. In D. Pimental, World soil erosion and conservation (pp. 27-62). Cambridge: Cambridge University Press.

Jagger, P., \& Pender, J. (2003). The role of trees for sustainable management of less-favored lands: The case of eucalyptus in Ethiopia. Forest Policy and Economics, 3(1), 83-95.

Kidane, T. (2008). Determinants of physical soil and water conservation practices: The case of Bati District, Oromia Zone, Amhara Region. Unpublished M.Sc. Thesis, Haramaya University, Ethiopia.

Kirui, O. K., \& Mirzabaev, A. (2014). Economics of land degradation in Eastern Africa (No. 128). ZEF Working Paper Series. Center for Development Research (ZEF), University of Bonn, Germany.

Kumar, P. (Ed.). (2010). The economics of ecosystems and biodiversity: Ecological and economic foundations. London, Hardback: UNEP/Earthprint.

Le, B. Q., Nkonya, E., \& Mirzabaev, A. (2014). Biomass productivity-based mapping of global land degradation hotspots. ZEF-Discussion Papers on Development Policy No. 185, Bonn, Germany.

Liniger, H. (2011). Sustainable land management in practice. United Nations: FAO (Food and Agriculture Organization).

Liniger, H. P., Mekdaschi, R., Studer, C. H., \& Gurtner, M. (2011). Sustainable land management in practice - guidelines and best practices for Sub-Saharan Africa. TerrAfrica, World Overview of Conservation Approaches and Technologies (WOCAT) and Food and Agriculture Organization of the United Nations (FAO).

MeKonen, G. (2002). Country partnership framework to combat land degradation \& poverty. Ethiopia: Global Mechanism.

Melaku, T. (2013). Sustainable land management program in Ethiopia: Linking Local REDD+ projects to national REDD+ strategies and initiatives. PowerPoint Presentation Made by National Program Coordinator of SLMP. April 29-May 1, 2013, Hawassa, Ethiopia.

National Review Report (2002). Government of Ethiopia, Addis Ababa.

Nkonya, E., Gerber, N., Baumgartner, P., von Braun, J., De Pinto, A., Graw, V., et al. (2011). The economics of land degradation: Toward an integrated global assessment. In F. Heidhues, J. von Braun, \& M. Zeller (Eds.), Development economics and policy series (vol. 66). Frankfurt A.M., Peter Lang GmbH.

Nkonya, E., Von Braun, J., Alisher, M., Bao Le, Q., Ho Young, K., Kirui, O., et al. (2013). Economics of land degradation initiative: Methods and approach for global and national assessments. ZEF-Discussion Papers on Development policy No. 183, Bonn, Germany.

Nkonya, E., von Braun, J., Mirzabaev, A., Le, B. Q., Young, K. H., Kato, E., et al. (2014). Economics of land degradation initiative: Methods and approach for global and national assessments (basic standards for comparable assessments). Draft for discussion. Center for Development Research (ZEF), University of Bonn.

Pender, J., Gebremedhin, B., Benin, S., \& Ehui, S. (2001). Strategies for sustainable development in the Ethiopian highlands. American Journal of Agricultural Economics, 83(5), 1231-1240.

Rudel, T. K., Schneider, L., Uriarte, M., Turner, B. L., DeFries, R., Lawrence, D., \& Grau, R. (2009). Agricultural intensification and changes in cultivated areas, 1970-2005. Proceedings of the National Academy of Sciences, 106(49), 20675-20680.

Shibru, T. \& Kifle, L. (1998). Environmental management in ethiopia: have the national conservation plans worked? Organization for Social Science Research in Eastern and Southern Africa (OSSRIA) Environmental Forum Publications Series No. 1, Addis Ababa.

Shiferaw, B., \& Holden, S. T. (1999). Soil erosion and smallholders' conservation decisions in the highlands of Ethiopia. World Development, 27(4), 739-752.

Sonneveld, B. S. (2002). Land under pressure: The impact of water erosion on food production in Ethiopia. Netherlands: Shaker Publishing. 
Sutcliffe, J. P. (1993). Economic assessment of land degradation in the Ethiopian highlands: A case study. Addis Ababa, Ethiopia: National Conservation Strategy Secretariat, Ministry of Planning and Economic Development. Addis Ababa, Ethiopia.

Teketay, D. (2001). Deforestation, wood famine, and environmental degradation in Ethiopia's highland ecosystems: Urgent need for action. Northeast African Studies, 8(1), 53-76.

Tesfa, A., \& Mekuriaw, S. (2014). The effect of land degradation on farm size dynamics and crop livestock farming system in Ethiopia: A review. Open Journal of Soil Science, 4, 1.

The Global Mechanism. (2007). Increasing finance for sustainable land management. The Global Mechanism of the UNCCD - Via Paolo di Dono 44 00142 Rome, Italy. Available online at www.global-mechanism.org. Accessed 31 May 2015.

The World Bank. (2013). Ethiopia overview: First economic update. 1818 H Street NW, Washington DC 20433, USA.

Vlek, P., Le, Q. B., \& Tamene, L. (2010). Assessment of land degradation, its possible causes and threat to food security in Sub-Saharan Africa. In R. Lal \& B. A. Stewart (Eds.), Food security and soil quality (pp. 57-86). Boca Raton, Florida: CRC Press.

von Braun, J., Algieri, B., \& Kalkuhl, M. (2014). World food system disruptions in the early 2000s: Causes, impacts and cures. World Food Policy, 1(1), 1-22.

von Braun, J., Gerber, N., Mirzabaev, A., \& Nkonya, E. M. (2013). The economics of land degradation (No. 147910). Bonn, Germany: University of Bonn, Center for Development Research (ZEF).

Wagayehu, B. (2003). Economics of soil and water conservation: Theory and empirical application to subsistence farming in the eastern Ethiopian highlands. Doctoral thesis, Swedish University of Agricultural Sciences, Uppsala, Sweden.

Yesuf, M., Mekonnen, A., Kassie, M., \& Pender, J. (2005). Cost of land degradation in Ethiopia: A critical review of past studies. http://www.efdinitiative.org/sites/default/files/costs_of_land_ degradation_in_ethiopia_v2_final.pdf.. Accessed 11 Sep 2015. 